\title{
Phytochemical Constituents of Leaves Essential oils of Achillea fragrantissima (Asteraceae) from Iraq
}

\author{
Karzan O. Qader ${ }^{1}$, Sahar A.A. Malik Al-Saadi², Ibrahim M. Faraj ${ }^{3}$ \\ ${ }^{1}$ Department of Biology, College of Science, University of Sulaimani, Kurdistan Region - F.R. Iraq \\ ${ }^{2}$ Department of Biology, College of Science, Basrah University, Basrah, F.R. Iraq \\ ${ }^{3}$ Department of Protected Agriculture, Bakrajo Technical Institute, Sulaimani Polytechnic University, Kurdistan Region -F.R. Iraq
}

\begin{abstract}
Essential oils of Achillea fragrantissima extract were prepared and analyzed by gas chromatography-mass spectrometry (GC-MS). A total of 57 phytochemical constituents of chemical compounds were identified in leaves of $A$. fragrantissima. The major constituents of the essential oil were camphor (34.50\%), 1, 8-cineole $(\mathbf{1 4 . 6 0 \%})$, artemisia ketone $(\mathbf{1 0 . 2 5 \%})$, and 3-thujanone $\mathbf{( 7 . 8 2 \% )}$. In addition, 43 components were present at $<1 \%$. From the 57

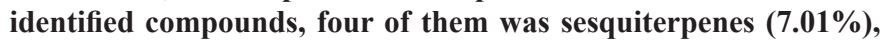
whereas 35 compounds were monoterpenes (61.40\%).
\end{abstract}

Index Terms-Achillea fragrantissima, camphor, essential oils, gas chromatography-mass spectrometry.

\section{INTRODUCTION}

Achillea fragrantissima (Forssk.) Sch. Bip. is a wild herbaceous shrub medicinal plant belonging to the Asteraceae family. Achillea contains around 130-140 perennial species worldwide, it is a white-woolly plant, with erect stems and is widespread in Europe and temperate areas of Asia, North America, and in North Africa, it is easily found growing in fields and on roadsides (Nemeth, 2010).

A. fragrantissima known as yarrow, in Arabic called Qaysoom. Most parts (leaves, flowers, and seeds) of A. fragrantissima contain high percentage of volatile oils, flavonoids, tannins, sterols and triterpenes monoterpene ketones, and sesquiterpene lactones (Batanouny, et al., 1999; Bakr, et al., 2014) fatty acids: Lauric, myristic, palmitic, stearic, linoleic, linolenic, and oleic (Al-Mustafa and Al-Thunibat, 2008). So that different parts of $A$. fragrantissima including fruits, leaves and branches have been used as a folk medicine for the treatment of various diseases. It is used as anti-inflammatory, antioxidant, antiproliferative capacities, antimicrobial, antifungal, antiviral,

ARO-The Scientific Journal of Koya University Volume VI, No 2(2018), Article ID: ARO.10425, 7 pages DOI: $10.14500 /$ aro. 10425

Received 28 May 2018; Accepted 12 December 2018

Regular research paper: Published 28 December 2018

Corresponding author's e-mail: saharmalik2010@gmail.com

Copyright (C) 2018 Karzan O. Qader, Sahar A.A. Malik Al-Saadi, Ibrahim M. Faraj. This is an open access article distributed under the Creative Commons Attribution License. and anticancer activity (Shalaby and Richler, 1964; Ageel, et al., 1989; Barel, et al., 1991; Al-Mustafa and Al-Thunibat, 2008; Soltan and Zaki, 2009; Elmann, et al., 2011; Hazem, et al., 2012; Vitalini, et al., 2013; Alenad, et al., 2013; Hammad, et al., 2014; and Choucry, 2017). Comparison between the essential oils of $A$. fragrantissima (Forssk.) Sch. Bip. and $A$. santolina L. (Asteraceae) studying their antimicrobial activity was reported by El-Shazly, et al., 2004.

The main constituents of $A$. fragrantissima are essential oil santolina alcohol, artemisia ketone, cis-thujone, and trans-thujone (El-Shazly, et al., 2004), whereas Hazem, et al. (2012) shown that 48 components were identified in the oils, and main compounds of oils were 4-terpineol $(15.65 \%)$, linalool $(11 \%)$, carvone $(9.42 \%), \beta$-phellandrene $(6.2 \%), \gamma$-terpinene $(5.6 \%), \beta$-pinene $(4.55 \%)$, verbenone $(4.42 \%)$, cedrol $(3.0 \%)$, and $\rho$-cymene $(2.95 \%)$. Choucry (2017) reported that 28 compounds were identified in the A. fragrantissima, caryophyllene oxide (23.50\%), terpinen4-ol (11.15\%), p-cymen-3-ol, viridiflorol, and guaiacol (9.84\%). In all these studies, chemical compositions were identified and the amount of the yields of essential oils was varied. The aim of this study, A. fragrantissima of leaves collected from Choman region, Erbil city, Iraq to extract essential oil and its compositions were analyzed using Gas chromatography and Mass spectrometry (GC-MS).

\section{Materials AND Methods}

\section{A. Plant Material}

The leaves of $A$. fragrantissima were collected from plants in flowering growth stage from Choman region, $160 \mathrm{~km}$ northeast Erbil city, Iraq, in September 2016 at Latitude $36.636310 \mathrm{~N}$, Longitude 44.886767 E, and Altitude $3607 \mathrm{~m}$. The plant was identified at the Basrah University. A voucher specimen was deposited at the herbarium of the Basrah Science, Faculty of Science, Basrah University, Iraq.

The meteorology of the study location for September 2016 was as follows: $26-28^{\circ} \mathrm{C}, 56 \%, 28 \mathrm{~mm}$, and $2.3 \mathrm{~m} / \mathrm{s}$ for temperature, relative humidity, rains, and wind speed, respectively, whereas the soil texture was sandy loam.

The samples were air-dried in the shade at room 
temperature until dried ( 2 weeks). To obtain the leaves essential oil, $150 \mathrm{~g}$ of dried leaves were crushed, and the method of hydrodistillation for $5 \mathrm{~h}$ using the Clevenger-type apparatus was used. The obtained essential oils were dried over anhydrous sodium sulfate and stored in the refrigerator $\left(-18^{\circ} \mathrm{C}\right)$ until used (Massada, 1976).

\section{B. GC-MS Analysis}

GC-MS analysis was carried out in the University of Basrah, College of Agriculture, Iraq using Shimadzu GCQP 2010 ultra gas chromatograph. The GC oven temperature was programmed from $40^{\circ} \mathrm{C}$ to $280^{\circ} \mathrm{C}$ at a rate of $15^{\circ} \mathrm{C} /$ min. Helium was used as carrier gas; inlet pressure was 96.1 $\mathrm{kPa}$; and linear velocity was $36.1 \mathrm{~cm} / \mathrm{s}$. Column flow was $1.00 \mathrm{~mL} / \mathrm{min}$, injector temperature: $280^{\circ} \mathrm{C}$; injection mode: split. MS scan conditions was carried using a ion source temperature of $200^{\circ} \mathrm{C}$, interface temperature, $280^{\circ} \mathrm{C}$ with detector gain $0.70 \mathrm{kV}+0.10 \mathrm{kV}$. Scan speed was 1666 , start 50 $\mathrm{m} / \mathrm{z}$, and then raised to end $800 \mathrm{~m} / \mathrm{z}$ (Vandendoo and Kratz, 1963). The components of the A. fragrantissima were identified by comparing the spectra with those of known compounds stored in the NIST library (2005). The identification of the phytochemical compounds was confirmed based on the molecular formula, peak area, and retention time (Fig. 1-6).

\section{RESULTS AND Discussion}

The GC-MS chromatogram of $A$. fragrantissima leaves extract (Fig. 7 and Table-1) showed 57 peaks indicate the presence of 57 compounds (phytochemical constituents).

Most of the chemical components from A. fragrantissima leaves are essential oil components including camphor $(34.50 \%), 1,8$-cineole $(14.60 \%)$, artemisia $(10.25 \%)$, and 3 -thujanone $(7.82 \%)$. In addition, 43 components were present at $<1 \%$ (Table 1 and Fig. 7), from all this component, the number and percentage of sesquiterpenes component were four compounds; methyl 3,4-tetradecadienoate, betacubebene, beta-selinene, and benzofuran, 7-cyclohexyl2,3-dihydro-2-methyl- which represented 7.01\% from all compounds in essential oil, and monoterpenes were 35 compounds $(61.40 \%)$. Our results agree with other literatures, monoterpenes are the principal components of Achillea essential oils (Zeedan, et al., 2014; Mottaghi, et al., 2016). Furthermore, 1, 8-cineole (20.1\%), camphor (15.6\%), and viridiflorol $(11.8 \%)$ the three most abundant monoterpene components (Toker, et al., 2003).

Most researchers reported that santolina alcohol, artemisia ketone, cis-thujone, and trans-thujone were the major constituents in A. fragrantissima (Shalaby and Ricchter, 1964; El-Deeb, 1985; Hifnawy, et al., 2001; El-Shazly, et al., 2004; Abaas, et al., 2013; and Alsohaili and Al-fawwaz, 2014). In addition, borneol and 1,8-cineole (Gohari, et al., 2011; Mazandarani, et al., 2013; Zeedan, et al., 2014). However, our results vary in the chemical composition of essential oils of A. fragrantissima, as well as the number and ratio of chemical components. These differences might be due to the diversity of the plant sources, different essential oil hydrodistillation procedures or growth conditions. In Egypt, the essential oil

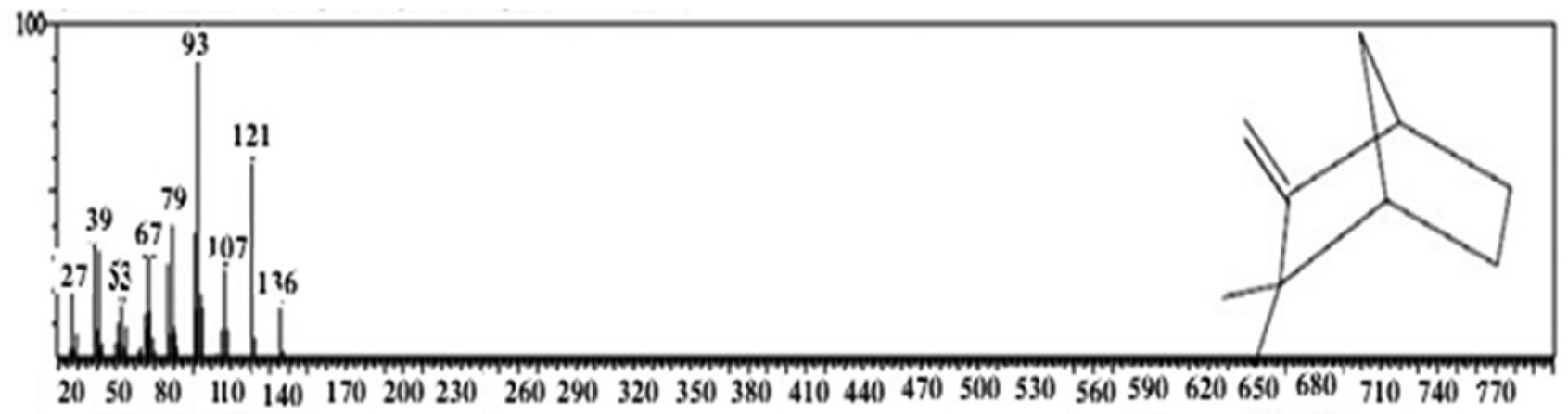

Fig. 1. A typical gas chromatogram of the camphene.

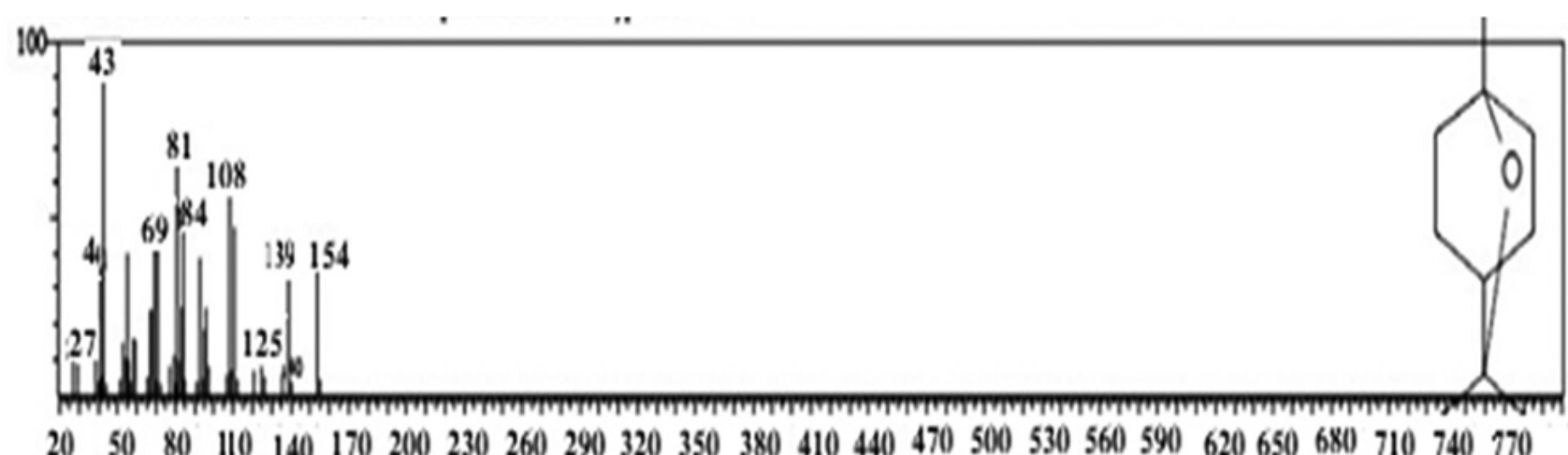

Fig. 2. A typical gas chromatogram of the 1, 8-cineole. 


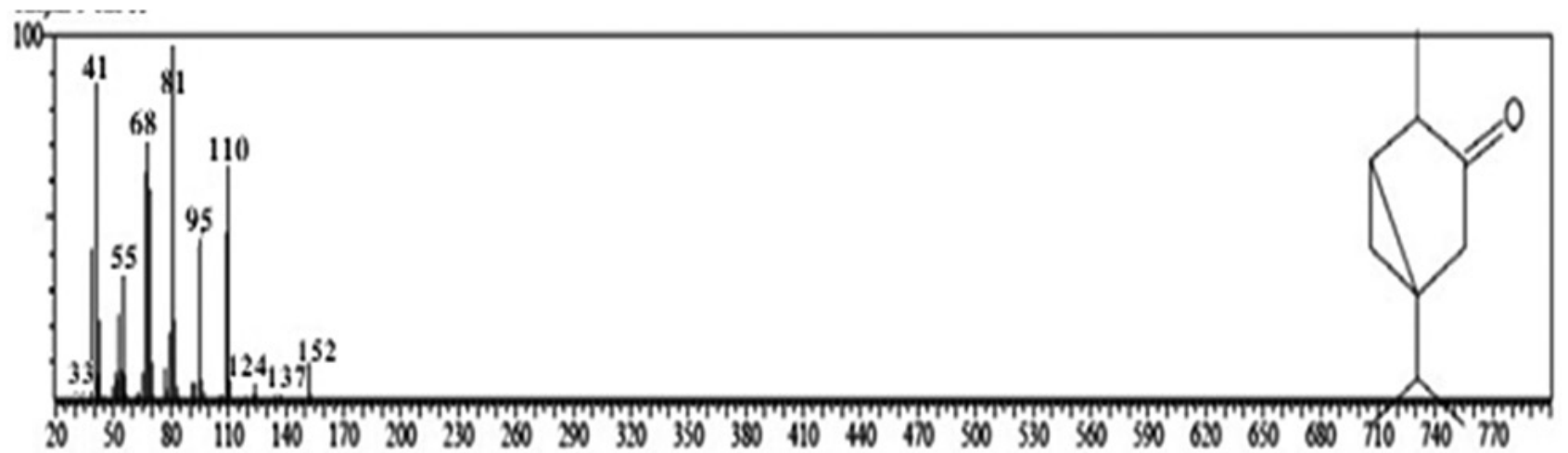

Fig. 3. A typical gas chromatogram of the 3-thujanone.

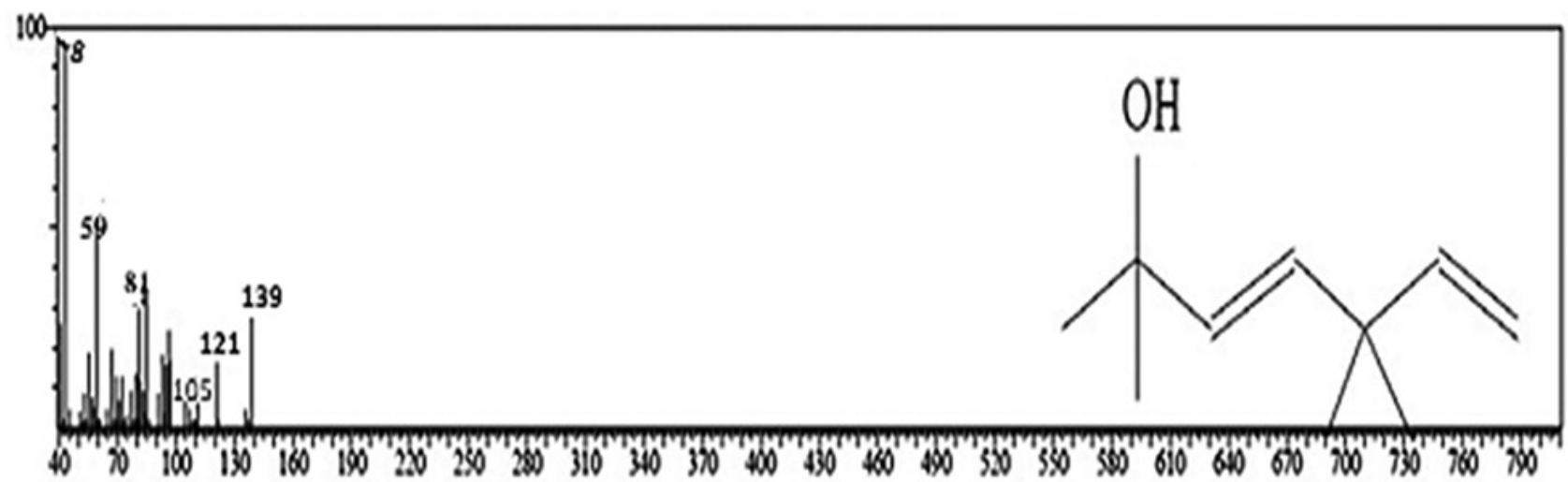

Fig. 4. A typical gas chromatogram of the yomogi alcohol.

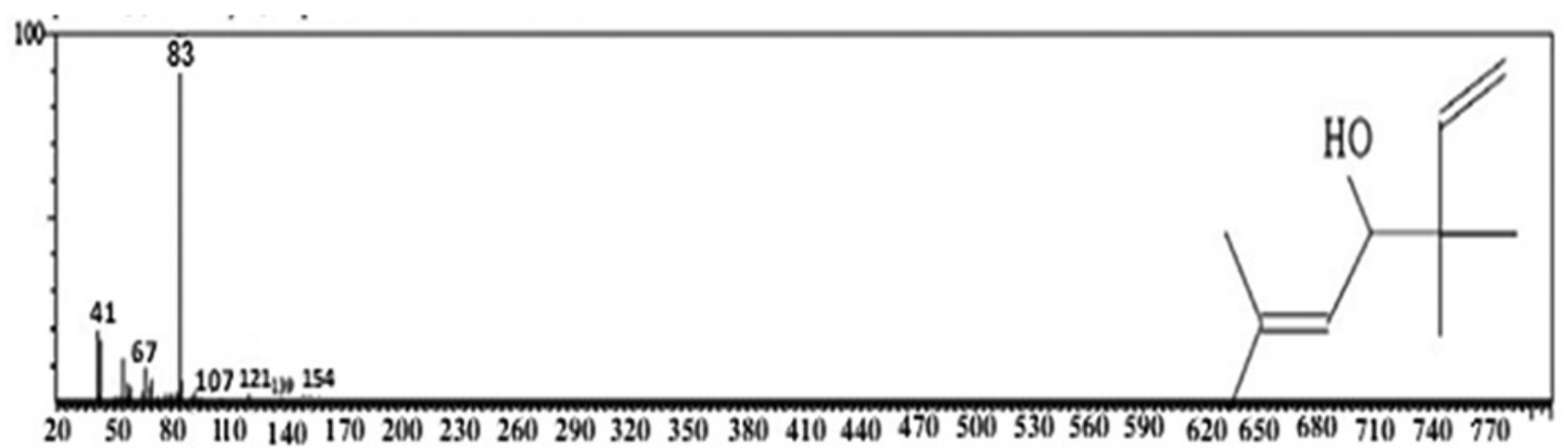

Fig. 5. A typical gas chromatogram of the artemisia alcohol.

obtained by hydrodistillation analyzed using GC-MS was found that the major components of $A$. fragrantissima were thujone (33.97\%), eucalyptol 8.17, artemisia alcohol (3.49\%), santolina triene (1.97\%), and terpineol (0.05\%) (Zeedan, et al., 2014). Alsohaili (2018) revealed that the chemical composition of essential oil of $A$. fragrantissima contains trans-sabinyl acetate $(0.75-10.20 \%), \alpha$-terpineol $\quad(3.53-$ $9.39 \%)$, trans-menth-2-en-1-ol (6.5-13.34\%), and $\beta$-thujone (11.34-22.11) using GC-MS, whereas Choucry (2017) reported that the major components were caryophyllene oxide $(23.50 \%)$ and 1-terpinen-4-ol (11.15). As well as in Jordan
15 compounds were identified of $A$. fragrantissima essential oil, artemisia ketone, $\beta$-sesquiphellandrene, and carvacrol are the major observed compounds with ratios 19.87, 14.57, and 13.44\%, respectively, (Alsohaili, and Al-fawwaz, 2014).

Although $\beta$-phellandrene, linalool, verbenone, and cedrol were found in other studies, they could not be detected in the plants from the present study. These variations may be due to the influence of geographical differences, physiological differences, and genetic factors (Adams, 2007). Environmental factors such as climate, soil, harvest season, method of drying, storage conditions, and even the part of the plant tissue 


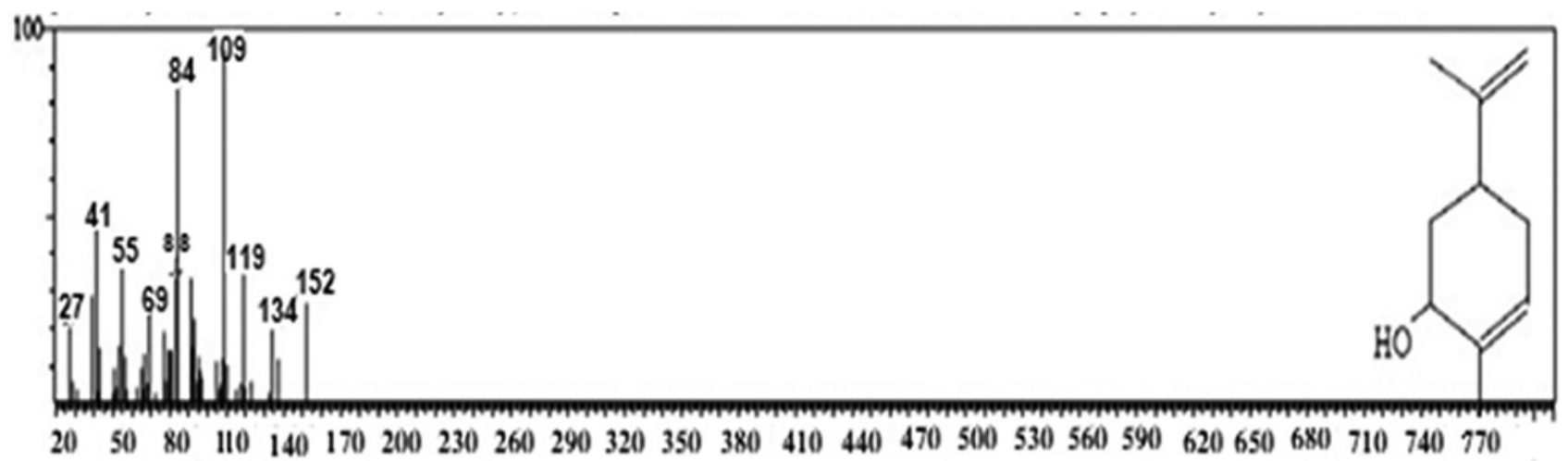

Fig. 6. A typical gas chromatogram of the trans-carveol.

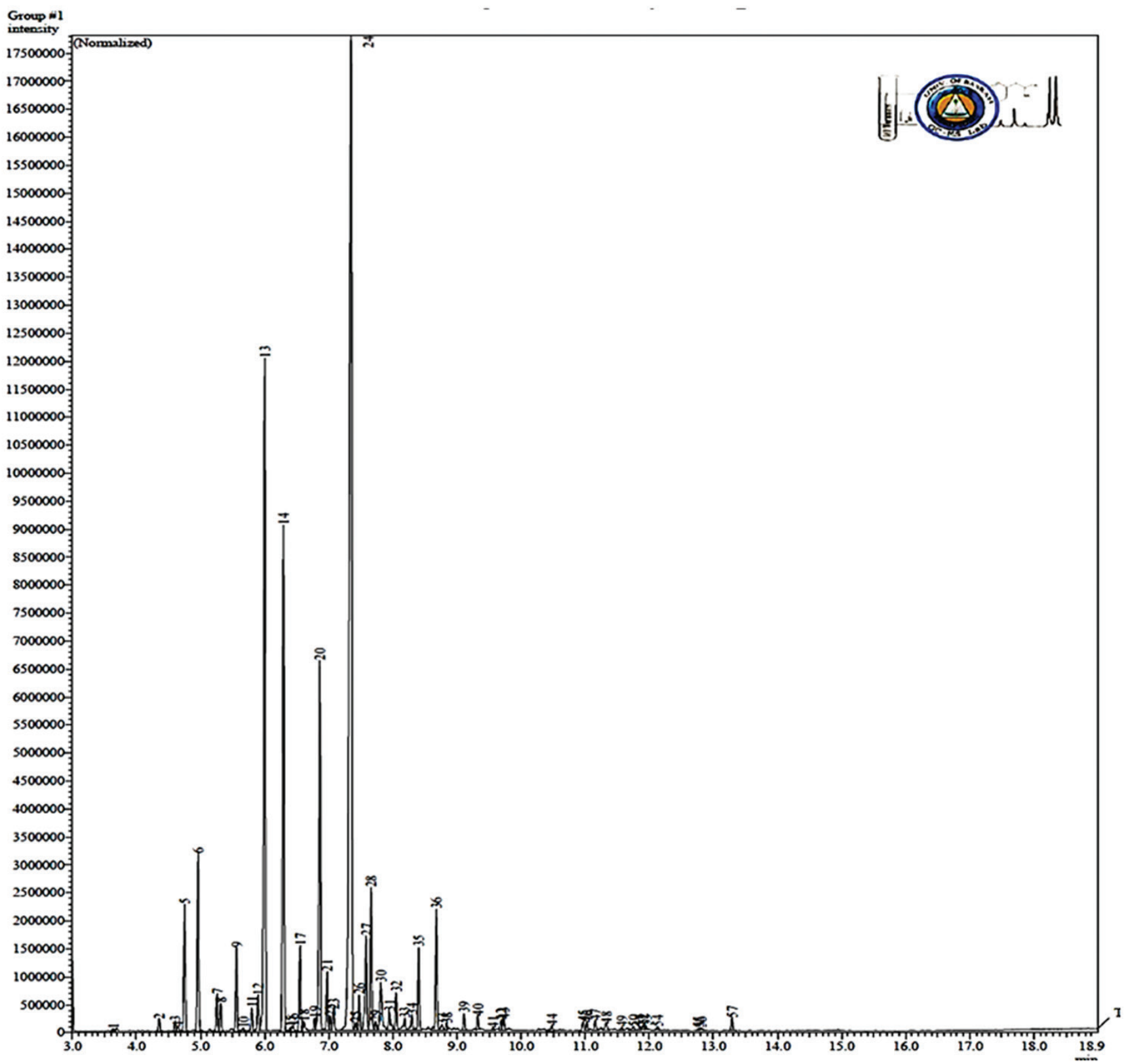

Fig. 7. Chromatogram of essential oil of Achillea fragrantissima leaves. 
TABLE I

Compounds IDENTIFIEd In the ESSENTIAL OIL OF $A$. FRAGRANTISSIMA LEAVES USING GC-MS

\begin{tabular}{|c|c|c|c|c|c|}
\hline $\begin{array}{l}\text { Peak } \\
\text { number }\end{array}$ & Formula & $\begin{array}{l}\text { Retention } \\
\text { time }\end{array}$ & $\begin{array}{l}\text { Retention } \\
\text { indices }\end{array}$ & Content (\%) & Components \\
\hline 1 & $\mathrm{C} 15 \mathrm{H} 42 \mathrm{P} 6 \mathrm{Pd} 2$ & 3.633 & 87409 & 0.06 & Dipalladium (0), tris [mu bis(dimethylphosphino) methane] \\
\hline 2 & $\mathrm{C} 10 \mathrm{H} 16$ & 4.353 & 375108 & 0.26 & Santolina \\
\hline 3 & $\mathrm{C} 10 \mathrm{H} 16$ & 4.598 & 295483 & 0.20 & Tricyclo[2.2.1.0 (2,6)]heptane, 1,7,7trimethyl-(Tricyclene) \\
\hline 4 & C41H39NO9 & 4.642 & 194053 & 0.13 & 1-O-p-Nitrobenzoyl-2,3,4,6-tetra-O-benzyl-betad-galactose \\
\hline 5 & $\mathrm{C} 10 \mathrm{H} 16$ & 4.749 & 36731873 & 2.54 & Alpha-Pinene \\
\hline 6 & $\mathrm{C} 10 \mathrm{H} 16$ & 4.959 & 5219456 & 3.61 & Camphene \\
\hline 7 & $\mathrm{C} 10 \mathrm{H} 16$ & 5.255 & 1085767 & 0.75 & Sabinene or Thujene \\
\hline 8 & $\mathrm{C} 10 \mathrm{H} 16$ & 5.313 & 835579 & 0.58 & Beta-pinene \\
\hline 9 & $\mathrm{C} 10 \mathrm{H} 18 \mathrm{O}$ & 5.559 & 2320358 & 1.60 & Yomogi alcohol \\
\hline 10 & $\mathrm{C} 10 \mathrm{H} 16$ & 5.664 & 96064 & 0.07 & Alpha-Phellandrene \\
\hline 11 & $\mathrm{C} 10 \mathrm{H} 16$ & 5.798 & 674863 & 0.47 & $(+)$-4-Carene \\
\hline 12 & $\mathrm{C} 10 \mathrm{H} 14$ & 5.896 & 1154110 & 0.80 & m-Cymene \\
\hline 13 & $\mathrm{C} 10 \mathrm{H} 18 \mathrm{O}$ & 5.997 & 21131715 & 14.60 & 1,8-Cineole \\
\hline 14 & $\mathrm{C} 10 \mathrm{H} 16 \mathrm{O}$ & 6.292 & 14835852 & 10.25 & Artemisia ketone \\
\hline 15 & $\mathrm{C} 38 \mathrm{H} 36 \mathrm{~N} 2 \mathrm{O} 4$ & 6.402 & 123812 & 0.09 & Estradiol17-benzoate-3-pphenylazobenzoate \\
\hline 16 & $\mathrm{C} 10 \mathrm{H} 18 \mathrm{O} 2$ & 6.440 & 179688 & 0.12 & alpha-Methyl-alpha- [4-methyl-3-pentenyl] oxiranemethanol \\
\hline 17 & $\mathrm{C} 10 \mathrm{H} 18 \mathrm{O}$ & 6.550 & 2429384 & 1.68 & Artemisia alcohol \\
\hline 18 & $\mathrm{C} 10 \mathrm{H} 16$ & 6.609 & 378420 & 0.26 & Bicyclo[4.1.0]hept-3-ene, 3,7,7trimethyl- \\
\hline 19 & $\mathrm{C} 9 \mathrm{H} 14$ & 6.779 & 442115 & 0.31 & Bicyclo (3.3.1)non-2-ene \\
\hline 20 & $\mathrm{C} 10 \mathrm{H} 16 \mathrm{O}$ & 6.859 & 11322487 & 7.82 & 3-Thujanone \\
\hline 21 & $\mathrm{C} 10 \mathrm{H} 16 \mathrm{O}$ & 6.973 & 1669169 & 1.15 & Thujone \\
\hline 22 & $\mathrm{C} 10 \mathrm{H} 14 \mathrm{O}$ & 7.020 & 438939 & 0.30 & Chrysanthenone \\
\hline 23 & $\mathrm{C} 10 \mathrm{H} 18 \mathrm{O}$ & 7.074 & 714612 & 0.49 & p-Menth-1(7)-en-9-ol \\
\hline 24 & $\mathrm{C} 10 \mathrm{H} 16 \mathrm{O}$ & 7.346 & 49947783 & 34.50 & Camphor \\
\hline 25 & $\mathrm{C} 9 \mathrm{H} 14 \mathrm{O}$ & 7.419 & 277954 & 0.19 & Sabina ketone \\
\hline 26 & $\mathrm{C} 10 \mathrm{H} 14 \mathrm{O}$ & 7.472 & 1066587 & 0.74 & Pinocarvone \\
\hline 27 & $\mathrm{C} 10 \mathrm{H} 18 \mathrm{O}$ & 7.582 & 3249579 & 2.24 & Borneol \\
\hline 28 & $\mathrm{C} 10 \mathrm{H} 18 \mathrm{O}$ & 7.658 & 4070212 & 2.81 & 4-Terpineol \\
\hline 29 & $\mathrm{C} 10 \mathrm{H} 14 \mathrm{O}$ & 7.730 & 323081 & 0.22 & 3,9-Epoxy-p-mentha-1,8(10)-diene \\
\hline 30 & $\mathrm{C} 10 \mathrm{H} 18 \mathrm{O}$ & 7.810 & 2218854 & 1.53 & alpha-Terpineol \\
\hline 31 & $\mathrm{C} 15 \mathrm{H} 26 \mathrm{O} 2$ & 7.944 & 780403 & 0.54 & Methyl 3,4-tetradecadienoate \\
\hline 32 & $\mathrm{C} 10 \mathrm{H} 16 \mathrm{O}$ & 8.050 & 1038638 & 0.71 & trans-carveol \\
\hline 33 & $\mathrm{C} 11 \mathrm{H} 22$ & 8.184 & 560224 & 0.39 & 2-Heptene, 5-ethyl-2,4-dimethyl- \\
\hline 34 & $\mathrm{C} 10 \mathrm{H} 14 \mathrm{O}$ & 8.294 & 561007 & 0.39 & Carvone \\
\hline 35 & $\mathrm{C} 10 \mathrm{H} 16 \mathrm{O}$ & 8.402 & 2400410 & 1.66 & Piperitone or carvomenthenone \\
\hline 36 & $\mathrm{C} 12 \mathrm{H} 20 \mathrm{O} 2$ & 8.676 & 3450467 & 2.38 & Acetic acid, 1,7,7-trimethyl-bicyclo [2.2.1] hept-2-yl ester \\
\hline 37 & $\mathrm{C} 10 \mathrm{H} 14 \mathrm{O}$ & 8.765 & 240528 & 0.17 & P-Cymene \\
\hline 38 & $\mathrm{C} 10 \mathrm{H} 14 \mathrm{O}$ & 8.835 & 208656 & 0.14 & Carvacrol \\
\hline 39 & $\mathrm{C} 12 \mathrm{H} 18 \mathrm{O} 2$ & 9.109 & 459884 & 0.32 & Carvyl acetate \\
\hline 40 & $\mathrm{C} 10 \mathrm{H} 12 \mathrm{O} 2$ & 9.323 & 386113 & 0.27 & 3-Allyl-6-methoxyphenol \\
\hline 41 & $\mathrm{C} 13 \mathrm{H} 18 \mathrm{O}$ & 9.559 & 74539 & 0.05 & Damascenone \\
\hline 42 & $\mathrm{C} 10 \mathrm{H} 14 \mathrm{O}$ & 9.689 & 401345 & 0.28 & 2H-Inden-2-one, 1,4,5,6,7,7a-hexahydro - 7a-methyl-, (S)- \\
\hline 43 & $\mathrm{C} 11 \mathrm{H} 14 \mathrm{O} 2$ & 9.727 & 321481 & 0.22 & Methyl eugenol \\
\hline 44 & $\mathrm{C} 15 \mathrm{H} 24$ & 10.479 & 234465 & 0.16 & beta-Cubebene \\
\hline 45 & С19H32O & 10.967 & 351364 & 0.24 & 1,9,12,15-octadecatetraene, 1 methoxy- \\
\hline 46 & $\mathrm{C} 10 \mathrm{H} 16 \mathrm{O}$ & 11.025 & 274199 & 0.19 & beta-Pinene oxide \\
\hline 47 & $\mathrm{C} 18 \mathrm{H} 30 \mathrm{O} 5$ & 11.155 & 393228 & 0.27 & 2-Butyloxycarbonyloxy-1,1,10trimethyl-6,9-epidioxydecalin \\
\hline 48 & $\mathrm{C} 10 \mathrm{H} 16 \mathrm{O}$ & 11.327 & 376046 & 0.26 & Pinane \\
\hline 49 & $\mathrm{C} 21 \mathrm{H} 30 \mathrm{O} 2$ & 11.571 & 134997 & 0.09 & 3-Phenylpropanoic acid, dodec-9-ynyl ester \\
\hline 50 & $\mathrm{C} 13 \mathrm{H} 20 \mathrm{O} 3$ & 11.751 & 200159 & 0.14 & Cyclopentaneacetic acid, 3-oxo-2-(2-pentenyl)-, methyl ester, [1 alpha, 2. Alpha (Z)]- \\
\hline 51 & $\mathrm{C} 10 \mathrm{H} 18 \mathrm{O}$ & 11.850 & 145938 & 0.10 & Cyclohexanol, 2-methyl-3-(1-methylethenyl)-, (1-alpha.,2-alpha.,3-alpha.)- \\
\hline 52 & $\mathrm{C} 15 \mathrm{H} 26 \mathrm{O}$ & 11.903 & 155051 & 0.11 & Eudesm-4 or beta-eudesmol) or beta-selinene \\
\hline 53 & $\mathrm{C} 15 \mathrm{H} 20 \mathrm{O}$ & 11.948 & 86696 & 0.06 & Benzofuran, 7-cyclohexyl-2,3-dihydro-2methyl- \\
\hline 54 & $\mathrm{C} 16 \mathrm{H} 24$ & 12.129 & 118661 & 0.08 & 1,3-Di (propen-1-yl) adamantane \\
\hline 55 & $\mathrm{C} 11 \mathrm{H} 16 \mathrm{O} 2$ & 12.768 & 80578 & 0.06 & Jasmololone \\
\hline 56 & $\mathrm{C} 11 \mathrm{H} 18 \mathrm{~N} 2$ & 12.808 & 136055 & 0.09 & $(+)-1-C y a n o-d-c a m p h i d i n e$ \\
\hline \multirow[t]{2}{*}{57} & $\mathrm{C} 16 \mathrm{H} 30 \mathrm{O} 2$ & 13.290 & 373362 & 0.26 & Z-7-Hexadecenoic acid \\
\hline & & & 144776160 & 100.00 & \\
\hline
\end{tabular}

GC-MS: Gas chromatography-mass spectrometry, A. fragrantissima: Achillea fragrantissima 
evaluated are all parameters that should be considered (Skotti, et al., 2014; Bouaziz, et al., 2015). Moreover, Farhat, et al. (2001) showed major seasonal changes in the composition of the oil. Therefore, the concentration and composition of the oil in our tests may resulted from seasonal and year differences during the collection of plants essential oil content of Achillea species changed according to the region therewith medicinal characters of the plants are also changed (Toncer, et al., 2010).

\section{CONCLUSION}

Results from this study have shown that the essential oil contains compounds with useful in pharmacological purposes. GC-MS analysis revealed that 57 different chemical components were identified in the A. fragrantissima leaves. The camphor compound recorded the highest amounts of $34.50 \%$. We also showed that leaves of A. fragrantissima contain different amounts of monoterpenes and sesquiterpenes. All the detected compounds can inter in making different medicinal drugs.

\section{REFERENCES}

Abaas, I.S., Majeed, M.J. and Majeed, A.H., 2013. Analysis with evaluation of drying temperature on essential oil content of Achillea fragrantissima and Artemisia herb-alba. International Journal of Pharmacy Pharmaceutical Science, 5(3), pp.913-914.

Abdel-Rahman, R.F., Alqasoumi, S.I., El-Desoky, A.H., Solimand, G.A., Paré, P.W. and Hegazy, M.E., 2015. Evaluation of the anti-inflammatory, analgesic and anti-ulcerogenic potentials of Achillea fragrantissima (Forssk.). South African Journal of Botany, 98, pp.122-127.

Adams, R.P., 2007. Identification of Essential oil Components by Gas Chromatography Mass Spectrometry. $4^{\text {th }}$ ed. Allured Publishing, Carol Stream, Illinois, p. 120 .

Ageel, A.M., Mossa, J.S., Al-Yahya, M.A., Al-Said, M.S. and Tariq, M., 1989. Experimental studies on antirheumatic crude drugs used in Saudi traditional medicine. Drugs under Experimental and Clinical Research, 15, pp.369-372.

Alenad, A.M., Al-Jaber, N.A., Krishnaswamy, S., Yakout, S.M., Al-Daghri, N.M. and Alokail, M.S., 2013. Achillea fragrantissima extract exerts its anticancer effect via in-duction of differentiation, cell cycle arrest and apoptosis in chronic myeloid leukemia (CML) cell line K562. Journal of Medicinal Plants Research, 7, pp.1561-1567.

Al-Mustafa, A.H. and Al-Thunibat, O.Y., 2008. Antioxidant activity of some Jordanian medicinal plants used traditionally for treatment of diabetes. Pakistan Journal of Biological Sciences, 11, pp.351-358.

Alsohaili, S., 2018. Seasonal variation in the chemical composition and antimicrobial activity of essential oil extracted from Achillea fragrantissima grown in Northern-Eastern Jordanian desert. Journal of Essential Oil-Bearing Plants, 21(1), pp.139-145.

Alsohaili, S.A. and Al-fawwaz, A.T., 2014. Composition and antimicrobial activity of Achillea fragrantissima essential oil using food model media. European Scientific Journal, 10(30), pp.1857-7881.

Bakr, R.O., Arafa, R.K., Al-Abd, A.M. and Elshishtawy, H.M., 2014. Phenolics of Achillea fragrantissima growing in Egypt and its cytotoxic activity. Journal of Medicinal Plants Research, 8(21), pp.763-771.
Barel, S., Segal, R. and Yashphe, J., 1991. The antimicrobial activity of the essential oil from Achillea fragrantissima. Journal of Ethnopharmacology, 33, pp.187-191.

Batanouny, K.H., Aboutabl, E., Shabana, M. and Soliman, F., 1999. Wild Medicinal Plants in Egypt. Academy of Scientific Research and Technology, Cairo, pp.1-56.

Bouaziz, A., Khennouf, S., Zarga, M.A., Abdalla, S., Baghiani, A. and Charef, N., 2015. Phytochemical analysis, hypotensive effect and antioxidant properties of Myrtus communis L. growing in Algeria. Asian Pacific Journal of Tropical Biomedicine, 5(1), pp.19-28.

Choucry, M.A., 2017. Chemical composition and anticancer activity of Achillea fragrantissima (Forssk.) Sch. Bip. (Asteraceae) essential oil from Egypt. Journal of Pharmacognosy and Phytotherapy, 9(1), pp.1-5.

El-Deeb, K., 1985. Chromatographic and Thermal Analysis of Certain Volatile Oil Containing Plants. Ph. D. Thesis: Faculty of Pharmacy, Cairo University.

Elmann, A., Mordechay, S., Erlank, H., Telerman, A., Rindner, M. and Ofir, R., 2011. Anti-neuroinflammatory effects of the extract of Achillea fragrantissima. BMC Complementary and Alternative Medicine, 11, p.98.

El-Shazly, A.M., Hafez, S.S., Wink, M., 2004. Comparative study of the essential oils and extracts of Achillea fragrantissima (Forssk.) Sch. Bip. and Achillea santolina L. (Asteraceae) from Egypt. Pharmazie, 59, pp.226-230.

Farhat, G.N., Affara, N.I. and Gali-Muhtasib, H.U., 2001. Seasonal changes in the composition of the essential oil extract of East Mediterranean sage (Salvia libanotica) and its toxicity in mice. Toxicon, 39, pp.1601-1605.

Gohari, A.R., Saeidnia, S., Mokhber-Dezfuli, N., Kiuchi, F.A., 2011. Review on phytochemistry and medicinal properties of the genus Achillea. Daru, 19, pp.173-186.

Hammad, H.M., Suzan, A., Simona-Carmen, M., Abuhamdah, S., Al-Jaber, F. and Afifi, U., 2014. Biological activities of the hydro-alcoholic and aqueous extracts of Achillea fragrantissima (Forssk.) grown in Jordan. Natural Science, 6(1), pp.23-30.

Hazem, A., Al-Charchafchi, F. and Ghazzawi, D., 2012. Biochemical, antibacterial and antifungal activity of extracts from Achillea fragrantissima and evaluation of volatile oil composition. Der Pharmacia Sinica, 3(3), pp.349-356.

Hifnawy, M.S., Rashwan, O.A. and Rabeh, M.A., 2001. Comparative Chemical and Biological Investigations of Certain Essential Oils Belonging to Families Asteraceae, Lamiaceae and Graminae. Vol. 39. Bulletin Faculty of Pharmacy Cairo University, Egypt, pp.35-53.

Massada, Y., 1976. Analysis of Essential Oil by Gas Chromatography and Spectrometry. John Wiley and Sons, New York.

Mazandarani, M., Mirdeilami, S.Z. and Pessarakli, M., 2013. Essential oil composition and antibacterial activity of Achillea millefolium L. from different regions in North east of Iran. Journal of Medicinal Plants Research, 7(16), pp.1063-1069.

Mottaghi, M., Shanjani, P.S., Jafari, A.A., Mirza, M. and Bihamta. M.R., 2016. Eessential oil composition of Achillea filipendulina, A. arabica and A. eriophora cultivated under temperate climate in Iran. Journal of Medicinal Plants and By Products, 2, pp.153-158.

Nemeth, E., 2010. Achillea species used medicinally in Hungary. Israel Journal of Plant Science, 58, pp.279-289.

NIST/EPA/NIH., 2005. Mass Spectral Library, Ver. NIST 05.

Shalaby, A.F. and Richter, G., 1964. Chromatographic investigation of the essential oil of Achillea fragrantissima. Journal of Pharmaceutical Science, 53, pp.1502-1505.

Skotti, E., Anastasaki, E., Kanellou, G., Polissiou, M. and Tarantilis, P.A., 2014. Total phenolic content, antioxidant activity and toxicity of aqueous extracts from 
selected Greek medicinal and aromatic plants. Industrial Crops and Products, 53, pp.46-54.

Soltan, M.M. and Zaki, A.K., 2009. Antiviral screening of forty-two Egyptian medicinal plants. Journal of Ethnopharmacology, 126, pp.102-107.

Toker, Z., Ozen, H.C., Clery, R.A., Owen, N.E., 2003. Essential oils of two Achillea species from Turkey. Journal of Essential Oil Research, 15, pp.100-110.

Toncer, O., Basbag, S., Karaman, S., Diraz, E. and Basbag, M., 2010. Chemical composition of the essential oils of some Achillea species growing wild in Turkey.

International Journal of Agriculture and Biology, 12, pp.527-530.
Vandendoo, H. and Kratz, P.D., 1963. A generalization of the retention index system including linear temperaturee programmed gas-liquid partition chromatography. Journal of Chromatography, 11, pp.463-471.

Vitalini, S., Iriti, M., Puricelli, C., Ciuchi, D., Segale, A. and Fico, G., 2013.

Traditional knowledge on medicinal and food plants used in Val San Giacomo (Sondrio, Italy)-an alpine ethnobotanical study. Journal of Ethnopharmacology, 145, pp.517-529.

Zeedan, G.S., Abdalhamed, A.M., Ottai, M.E., Abdelshafy, S. and Abdeen, E., 2014. Antimicrobial, antiviral activity and GC-MS analysis of essential oil extracted from Achillea fragrantissima plant growing in Sinai Peninsula, Egypt. Journal of Microbial and Biochemical Technology, S8, pp.6-8. 